\title{
Site report for USGS test holes drilled at Cape Charles, Northampton County, Virginia, in 2004
}

By Gregory S. Gohn, Ward E. Sanford, David S. Powars, J. Wright Horton, Jr., Lucy E. Edwards, Roger H. Morin, and Jean M. Self-Trail

Open-File Report 2007-1094

U.S. Department of the Interior

U.S. Geological Survey 


\section{U.S. Department of the Interior DIRK KEMPTHORNE, Secretary}

\section{U.S. Geological Survey \\ Mark D. Myers, Director}

U.S. Geological Survey, Reston, Virginia

2007

For product and ordering information:

World Wide Web: http://www.usgs.gov/pubprod

Telephone: 1-888-ASK-USGS

For more information on the USGS - the Federal source for science about the Earth, its natural and living resources, natural hazards, and the environment:

World Wide Web: http://www.usgs.gov

Telephone: 1-888-ASK-USGS

Suggested citation:

Gohn, G.S., Sanford, W.E., Powars, D.S., Horton, J.W., Jr., Edwards, L.E., Morin, R.H., and Self-Trail, J.M., 2007, Site report for USGS test holes drilled at Cape Charles,

Northampton County, Virginia, in 2004: U.S. Geological Survey Open-File Report 2007-1094 $22 \mathrm{p}$.

Any use of trade, product, or firm names is for descriptive purposes only and does not imply endorsement by the U.S. Government.

Although this report is in the public domain, permission must be secured from the individual copyright owners to reproduce any copyrighted material contained within this report. 


\section{Contents}

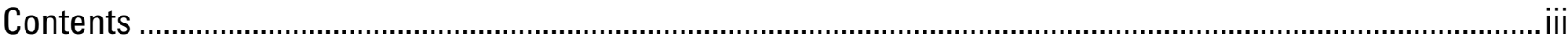

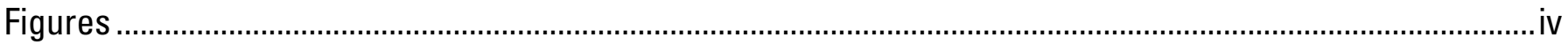

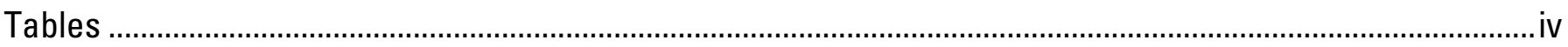

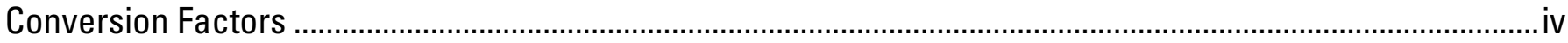

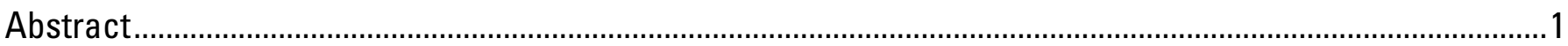

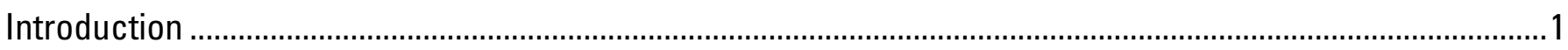

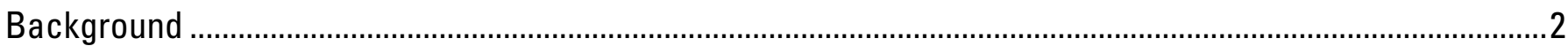

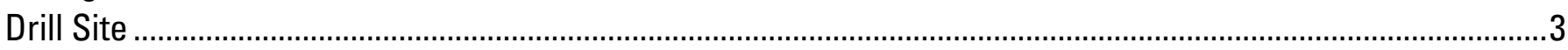

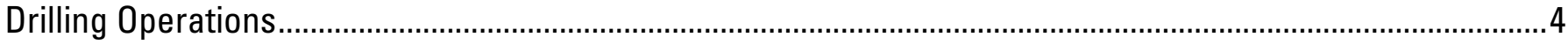

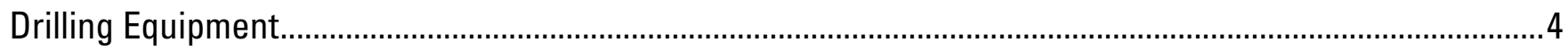

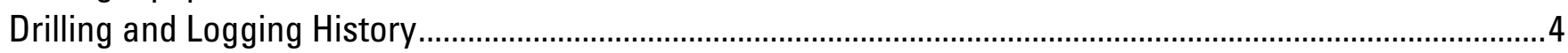

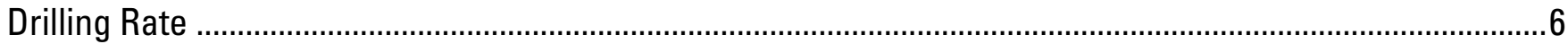

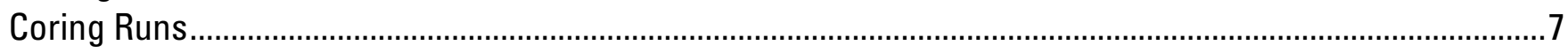

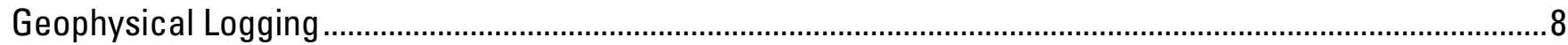

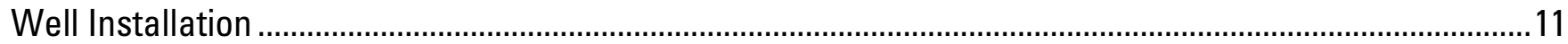

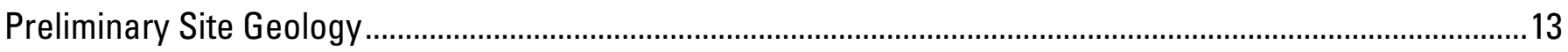

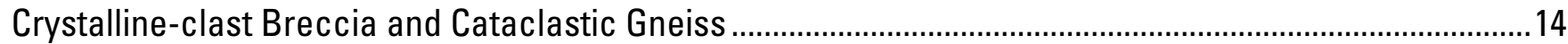

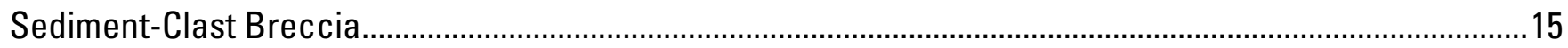

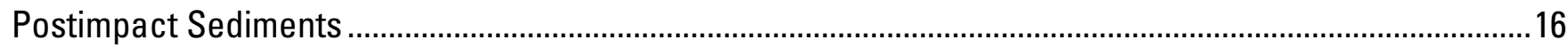

Upper Eocene Section - Chickahominy Formation $(1,163 \mathrm{ft}$ to $993 \mathrm{ft}$ ) .....................................................16

Oligocene Section - Delmarva Beds, Drummonds Corner Beds, Old Church Formation (993 to $955 \mathrm{ft}$ ) ...17

Lower and Middle Miocene Section - Calvert and Choptank Formations (955 ft to $606 \mathrm{ft}$ ) .....................17

Upper Miocene Section - St. Marys and Eastover Formations (606 ft to $168 \mathrm{ft}$ ).....................................18

Pliocene Section - Yorktown and Chowan River Formations (168 ft to $32 \mathrm{ft}$ ) .............................................18

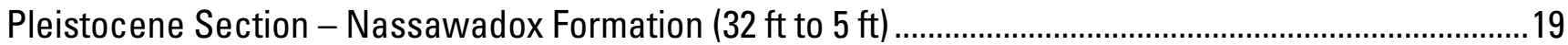

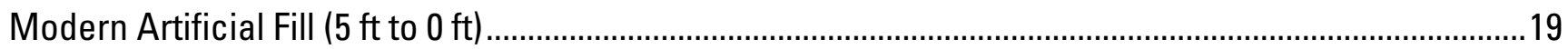

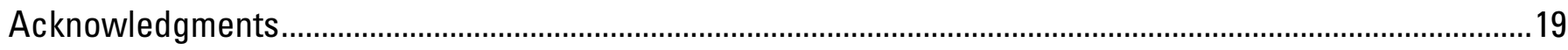

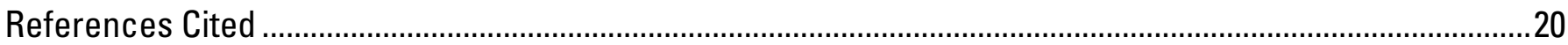

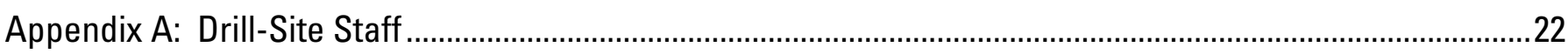

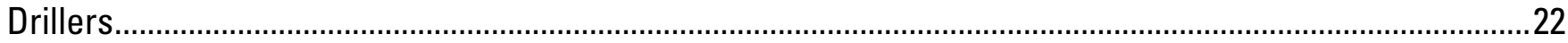

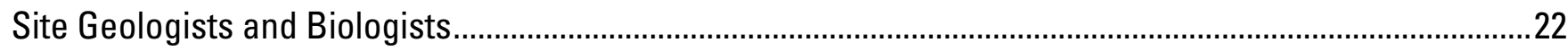

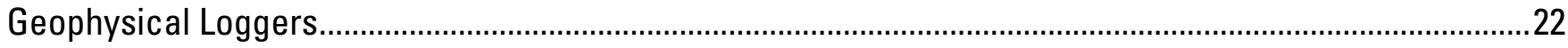




\section{Figures}

Figure 1. Regional map showing the location of the Chesapeake Bay impact structure and the USGS-STP drill site at Cape Charles (yellow circle) .....................................................................................................

Figure 2. Topographic map showing the location of the USGS-STP drill site near Cape Charles, Va................

Figure 3. Photograph of the USGS-STP drill site during drilling operations in May 2004....................................

Figure 4. Drill penetration rate for the USGS-STP2 test hole.........................................................................

Figure 5. Composite of geophysical logs obtained in test hole USGS-STP2. See list of Conversion Factors (above) to convert SI units to Inch/Pound units. ....................................................................................... Figure 6. Diagram showing water wells 62G-24 (deep well) and 62G-25 (shallow well) in the USGS-STP2 test

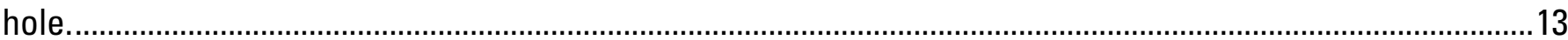

Figure 7. Generalized geologic column, and gamma-activity and short-normal-resistivity logs, from the USGS-STP2 test hole.

\section{Tables}

Table 1. Data for coring runs in the USGS-STP2 test hole............................................................................

Table 2. Record of geophysical logging activities in the USGS-STP2 test hole.

\section{Conversion Factors}

Inch/Pound to SI

\begin{tabular}{lcl}
\hline \multicolumn{1}{c}{ Multiply } & \multicolumn{1}{c}{ By } & \multicolumn{1}{c}{ To obtain } \\
\hline Length & & \\
\hline inch (in.) & 2.54 & centimeter $(\mathrm{cm})$ \\
inch (in.) & 25.4 & millimeter $(\mathrm{mm})$ \\
foot (ft) & 0.3048 & meter $(\mathrm{m})$ \\
mile (mi) & 1.609 & kilometer $(\mathrm{km})$ \\
\hline Volume & & \\
\hline gallon (gal) & 3.785 & liter $(\mathrm{L})$ \\
\hline Flow rate & & \\
\hline gallon per minute $(\mathrm{gal} / \mathrm{min})$ & 0.06309 & liter per second $(\mathrm{L} / \mathrm{s})$ \\
\hline Pressure & & \\
\hline pound per square inch $\left(\mathrm{lb} / \mathrm{in}^{2}\right)$ & 6.895 & kilopascal $(\mathrm{kPa})$ \\
\hline
\end{tabular}




\section{SI to Inch/Pound}

\begin{tabular}{|c|c|c|}
\hline Multiply & By & To obtain \\
\hline \multicolumn{3}{|l|}{ Length } \\
\hline meter $(\mathrm{m})$ & 3.281 & foot $(\mathrm{ft})$ \\
\hline kilometer (km) & 0.6214 & mile (mi) \\
\hline meter $(\mathrm{m})$ & 1.094 & yard (yd) \\
\hline
\end{tabular}

Horizontal coordinate information is referenced to the North American Datum of 1988 (NAD 88). 


\title{
Site report for USGS test holes drilled at Cape Charles, Northampton County, Virginia, in 2004
}

\author{
By Gregory S. Gohn, Ward E. Sanford, David S. Powars, J. Wright Horton, Jr., Lucy E. Edwards, \\ Roger H. Morin, and Jean M. Self-Trail
}

\begin{abstract}
The U.S. Geological Survey drilled two test holes near Cape Charles, Virginia, during May and June 2004, as part of an investigation of the buried, late Eocene Chesapeake Bay impact structure. The first hole is designated as the USGS-Sustainable Technology Park test hole \#1 (USGS-STP1). This test hole was abandoned at a depth of $300 \mathrm{ft}$; cuttings samples were collected, but no cores or geophysical logs were acquired. The second hole is designated as the USGSSustainable Technology Park test hole \#2 (USGS-STP2). This test hole was drilled to a depth of 2,699 ft. Cores were collected between depths of 1,401.7 ft and 1,420.7 ft and between 2,440.0 ft and 2,699.0 ft. Cuttings samples were collected from the uncored intervals below 280-ft depth. Interim sets of geophysical logs were acquired during the drilling operation, and one final set was acquired at the end of drilling. Two wells were installed in the USGS-STP2 test hole. The deep well (designated 62G-24) was screened between 2,260 ft and 2,280 ft, and the shallow well (designated 62G-25) was screened between 1,360 ft and 1,380 ft. Ground-water salinities stabilized at 40 parts per thousand for the deep well and 20 parts per thousand for the shallow well. The geologic section encountered in the test holes consists of three main units: (1) Eocene, Oligocene, Miocene, Pliocene, and Pleistocene sands and clays are present between land surface and a depth of 1,163 ft; (2) sediment-clast breccias of the impact structure are present between depths of 1,163 ft and 2,150 ft; and (3) crystalline-clast breccias and cataclastic gneiss of the impact structure are present between depths of 2,150 ft and 2,699 ft.
\end{abstract}

\section{Introduction}

The U.S. Geological Survey (USGS) drilled two scientific test holes at Cape Charles, Northampton County, Virginia, during May and June 2004. These test holes are part of a multiagency study of the buried Chesapeake Bay impact structure, which underlies Northampton County and surrounding areas. Sanford and others (2004) published a brief summary of the drilling operations and results at Cape Charles. This report presents a more detailed operational summary, and a preliminary geologic summary, for the two test holes.

The Cape Charles test holes are designated as the USGS Sustainable Technology Park test hole \#1 (USGS-STP1) and the USGS Sustainable Technology Park test hole \#2 (USGS-STP2). USGS-STP1 had to be abandoned at a depth of $300 \mathrm{ft}$ because of a nearsurface sediment washout. No cores or geophysical logs were collected from this hole; cuttings were collected from the entire $300-\mathrm{ft}$ section. USGS-STP2 reached a total depth of 2,699 ft. Cores were collected from two intervals in this hole, and four geophysical logging runs were completed; cuttings were collected from the uncored intervals below a depth of $280 \mathrm{ft}$. The two test holes are located about $65 \mathrm{ft}$ apart, 
and their geologic sections are considered collectively in this report. This section consists of postimpact sediments that overlie sediment-clast breccias, crystalline-clast breccias, and cataclastic gneiss within the impact structure.

\section{Background}

The Chesapeake Bay impact structure formed about 35 million years ago during the late Eocene when a comet fragment or asteroid struck the U.S. Atlantic continental shelf in the area now occupied by the southern part of Chesapeake Bay and adjacent landmasses in the Virginia Coastal Plain. The resulting structure is an approximately circular, 53-mile-diameter crater centered near the town of Cape Charles, Va. (Fig. 1). The geologic materials within the structure now lie buried beneath hundreds of feet of younger Cenozoic marine sediments. Additional information about the Chesapeake Bay impact structure is available in numerous published studies, including Koeberl and others (1996), Poag (1997), Powars and Bruce (1999), Powars (2000), Edwards and others, (2004a), Poag and others (2004), and Horton and others (2005a, b).

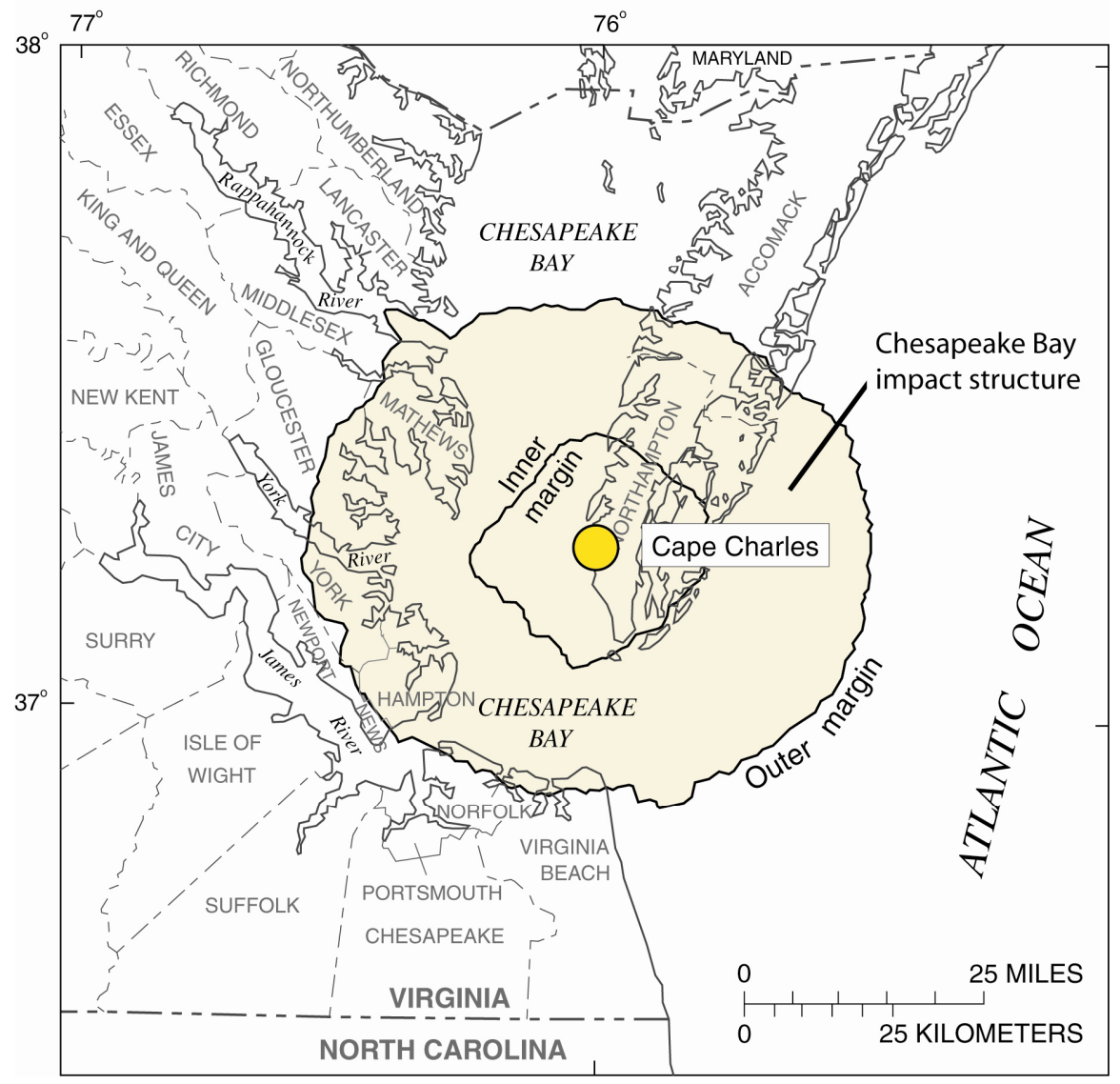

Figure 1. Regional map showing the location of the Chesapeake Bay impact structure and the USGS-STP drill site at Cape Charles (yellow circle).

The Chesapeake Bay impact structure spatially coincides with a long known, but poorly explained inland zone of salty ground water. This spatial association strongly suggests a genetic association (Powars and Bruce, 1999; McFarland and Bruce, 2005). The presence of the inland salt-water zone has practical significance because rapid population and commercial growth in areas 
above and near to the salt-water zone requires an ever-increasing supply of fresh water (Emry and Miller, 2004). Detailed knowledge of the distribution of the salt-water zone and its formative processes are needed to determine whether increased ground-water pumping in adjacent areas will lead to migration of the salt water.

\section{Drill Site}

The USGS-STP test holes are located near the property line between the Cape Charles Sustainable Technology Park (STP) and the Bayshore Concrete Products plant, about 0.3 miles south of Cape Charles harbor (Fig. 2). The holes are located immediately west of the paved parking lot at the Sustainable Technology Park on a narrow grassy strip between the pavement and a wooded area to the west (Fig. 3). This location is near the southeastern corner of the Cape Charles 7.5-min topographic quadrangle (USGS, 1968).

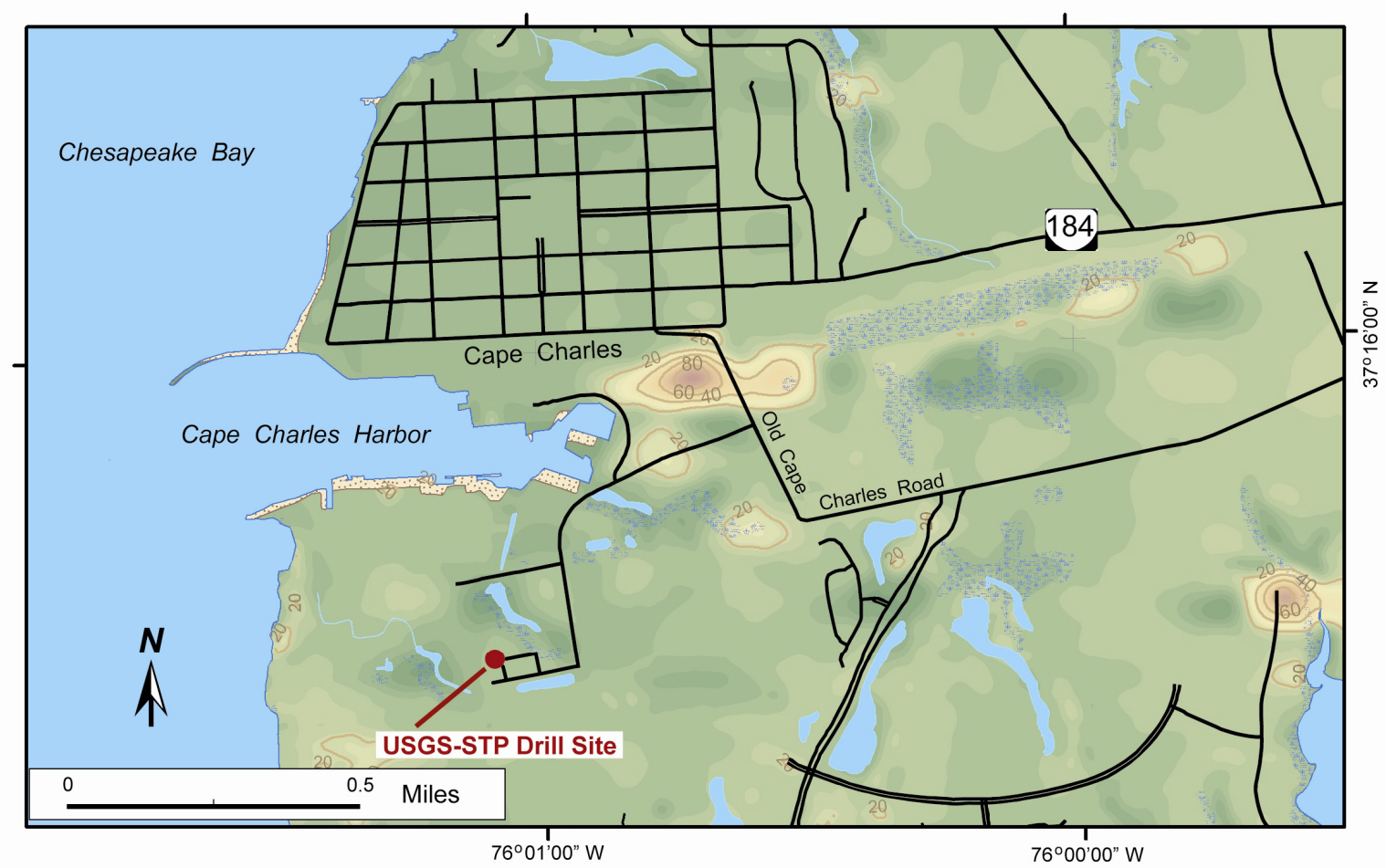

Figure 2. Topographic map showing the location of the USGS-STP drill site near Cape Charles, Va.

The latitude and longitude of the USGS-STP2 test hole are $37^{\circ} 15^{\prime} 33.17^{\prime \prime} \mathrm{N}$ and 76 01 '04.83" W. Coordinates were obtained using a Magellan ProMark X GPS receiver and were differentially post processed. The datum is NAD 88, and the accuracy is submeter (sub-yard). The surface elevation at the drill site is $7 \mathrm{ft}( \pm 1 \mathrm{ft})$, as estimated from the 1:24,000-scale topographic map of the Cape Charles 7.5-min quadrangle. 


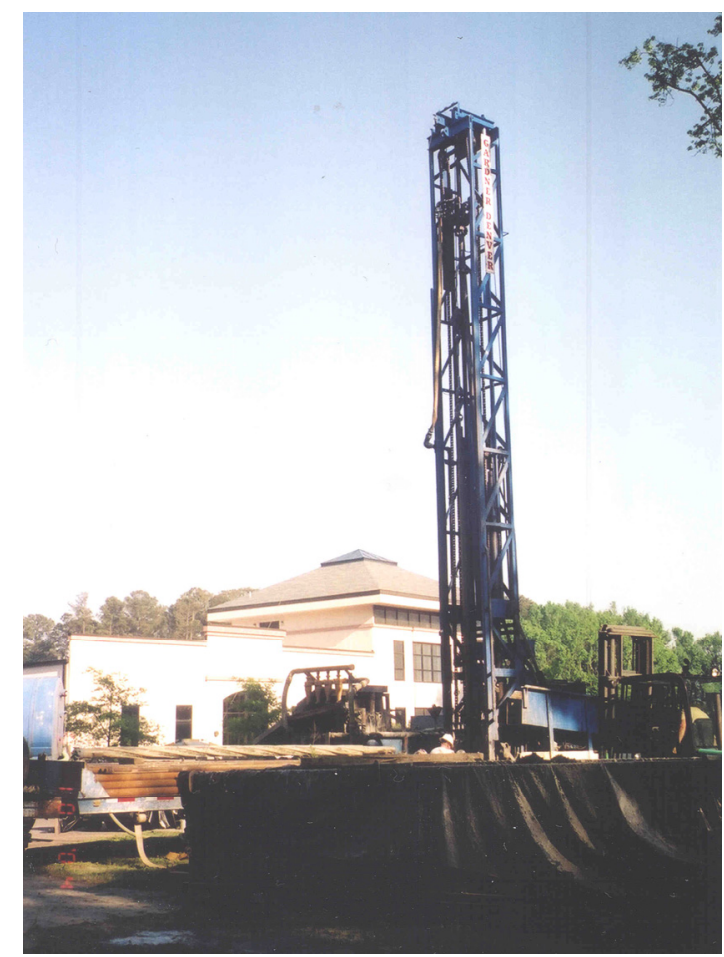

Figure 3. Photograph of the USGS-STP drill site during drilling operations in May 2004.

\section{Drilling Operations}

\section{Drilling Equipment}

The USGS-STP test holes were drilled by crews from the USGS Central Region Research Drilling Project between May 8 and May 26, 2004. Well installation and development continued into early June 2004. The test holes were drilled, and the wells installed, using a Gardner-Denver $17 \mathrm{~W}$ hydraulic rotary rig.

Most of the drilling was conducted using 4.5-inch-diameter drilling rods and variety of wing (drag), roller, and claw bits. Coring was conducted using 3.7-inch-diameter coring rods and a tenfoot-long, Christensen H-size core barrel. The nominal core diameter is 2.5 inches. Mud viscosities were measured periodically using a Marsh funnel viscometer. Mud temperatures were not recorded.

\section{Drilling and Logging History}

The drill rig arrived at Cape Charles on Friday, May 7, 2004, and drilling commenced on the morning of May $8^{\text {th }}$. Drilling was halted at a depth of $18 \mathrm{ft}$, and 12-inch-diameter steel surface casing was installed to that depth by the end of work on May $8^{\text {th }}$. There was no overnight drilling on May 8-9. Drilling continued on the morning of May $9^{\text {th }}$, and a depth of $300 \mathrm{ft}$ was reached by the end of work on that day. There was no overnight drilling on May 9-10. The crew returned to the drill site at 6:00 am on May 10 ${ }^{\text {th }}$ to discover that the surface casing had dropped slightly below land surface overnight and that a washout cavern had developed in the sandy surficial sediments. As a result, the drill rig was moved about $65 \mathrm{ft}$ to the south. 
The 300-ft-deep hole is USGS Sustainable Technology Park test hole \#1. No geophysical logs or cores were acquired in this hole; however, cuttings were collected at 20 -ft intervals from the entire 300-ft section.

The drilling of the second test hole, USGS Sustainable Technology Park test hole \#2, started at 4:45 pm on May $10^{\text {th }}$ and reached a depth of $60 \mathrm{ft}$ by 5:30 pm. At that time, $56 \mathrm{ft}$ of 12 -inchdiameter, schedule 40, PVC casing was placed in the hole. About 220 gal of cement were placed around the casing between land surface and a depth of about $37 \mathrm{ft}$. Work at the drill site ended at 9:00 pm on May $10^{\text {th }}$; there was no overnight drilling on May 10-11. On the morning of May $11^{\text {th }}$, the crew repaired the pump on the shaker trailer and installed the side-discharge tube and cuttings trough to facilitate sample collection. Round-the-clock drilling started at 1:55 pm using a 10 and 5/8-inch-diameter roller bit. Drilling continued to a depth of $394 \mathrm{ft}$ at 11:12 pm on May $11^{\text {th }}$ without significant mechanical problems or weather delays. The collection of cuttings samples began at a depth of $280 \mathrm{ft}$; no cuttings were collected above this depth in USGS-STP2.

The drill crew began to pull the rods from the hole at 11:14 pm on May $11^{\text {th }}$ in preparation for geophysical logging and casing installation. The first logging probe (caliper) was lowered into the hole at 12:30 am on May $12^{\text {th }}$, and the borehole size was measured from about 390-ft depth to the land surface. The caliper log indicated that the borehole necked down to a diameter of about 2 inches at depths of $126 \mathrm{ft}$ to $130 \mathrm{ft}$. The multifunction and sonic-velocity probes could not pass this constriction, and data were collected with those tools only above 125-ft depth. At 4:45 am, the drillers started reaming the borehole to allow additional geophysical logging to the total depth of the hole. Reaming was completed at 9:00 am, and the crew began to pull the rods from the hole at that time. Geophysical logging resumed at 9:55 am, and the full length of the open borehole was logged with the caliper, multifunction, sonic-velocity, neutron-porosity, and gamma-gamma density tools.

The drill crew began placing 8-inch (inside diameter) steel casing into the borehole at 4:45 pm. The casing reached a depth of $394 \mathrm{ft}$ at $8: 25 \mathrm{pm}$, and cementing of the casing began at the time. By 10:30 pm on May $12^{\text {th }}, 442$ gal of cement had been placed in and around the steel casing. Drilling was suspended until 3:15 pm on May $13^{\text {th }}$ to allow the cement to harden. At that time, the crew began replacing the drill rods fitted with a 7 and $7 / 8$-inch-diameter wing bit into the hole to drill out the cement plug.

Normal drilling with the wing bit resumed at 5:30 pm on May $13^{\text {th }}$ at the previously reached depth of $394 \mathrm{ft}$. Drilling proceeded only to a depth of $400 \mathrm{ft}$ and was then halted at 6:00 pm to await the arrival of a shipment of drilling mud additives. Drilling resumed at 7:59 pm, and a depth of $500 \mathrm{ft}$ was reached at about midnight on May $13^{\text {th }}$. Drilling continued on May $14^{\text {th }}$ and reached a depth of $940 \mathrm{ft}$ at 9:35 pm. At that time, the crew began pulling the rods from the borehole in preparation for repairing the mast-line cable. The cable was replaced, and drilling resumed at 12:14 pm on May $15^{\text {th }}$ using a 7 and 7/8-inch-diameter, three-cone roller bit. Drilling continued until 8:00 pm on that day when a depth of 1,100 ft was reached. At 8:15 pm, the crew began pulling the rods from the borehole in order to change bits. The roller bit was replaced with a 7 and 7/8-inch-diameter wing bit, and the rods were back to the bottom of the hole by 2:55 am on May $16^{\text {th }}$. The borehole was reamed where needed and extensively flushed during the replacement of the rods into the hole.

A depth of 1,340 ft was reached at 7:28 $\mathrm{pm}$ on May $16^{\text {th }}$ at which time the crew began pulling the rods to change back to the 7 and 7/8-inch-diameter roller bit in the hope of increasing the drilling rate. The roller bit was placed back to the previous depth of 1,340 ft at 2:10 am on May $17^{\text {th }}$. At that time, the crew emptied the mud system and mixed new drilling mud. Drilling resumed at 3:40 am, and a depth of 1,400 ft was reached at 10:30 am. At that time, the drillers began pulling the rods from the hole in preparation for geophysical logging and wireline coring. 
Geophysical logging operations to $1,400 \mathrm{ft}$ consisted of collecting caliper, density, multifunction and sonic-velocity logs and were completed at 9:10 pm on May $17^{\text {th }}$. Assembly of the coring equipment began shortly thereafter, and the crew began placing the 3.7-inch-diameter coring rods with an H-size sampling system into the test hole at 10:27 pm. Placing the sampling system into the hole proved difficult as the coring bit was blocked repeatedly by sediment during its descent, and the rod string had to be raised to a shallower depth to re-establish mud flow on each occasion. The problem was corrected by removing the inner sample barrel from the outer barrel, thereby allowing better mud flow through the drill bit. Subsequently the inner barrel was placed downhole inside the rods, and it latched into place within the outer barrel without further difficulties. Two 10-ft coring runs were then completed between 3:05 pm and 4:42 pm on May $18^{\text {th }}$ at depths of about $1,400 \mathrm{ft}$ to $1,420 \mathrm{ft}$ (Table 1).

After the coring runs, the coring rods were removed from the hole, and the drilling rods were returned to the borehole with a 6 and 3/4-inch-diameter claw (carbide-tooth) bit attached. The rods reached the bottom of the hole at $1,420 \mathrm{ft}$ at 11:50 pm on May $18^{\text {th }}$, and drilling resumed at 1:17 am on May $19^{\text {th }}$. Drilling continued without equipment problems and only minor thunderstorm delays until a depth of 2,440 ft was reach at 6:44 pm on May $22^{\text {nd }}$. During this fourday period, the drill bit reached depths of $1,780 \mathrm{ft}$ at about midnight on May $19^{\text {th }}, 2,120 \mathrm{ft}$ at about midnight on May $20^{\text {th }}$, and 2,240 ft at about midnight on May $21^{\text {st }}$. The decision to switch to continuous coring operations was made on May $22^{\text {nd }}$.

Wireline coring began at 9:44 pm on May $23^{\text {rd }}$. The crew completed twelve coring runs to a depth of 2,549 ft before midnight on May $24^{\text {th }}$. Eleven coring runs were completed on May 25th to a depth of 2,659 ft. Four coring runs were completed by 11:37 am on May $26^{\text {th }}$, thereby bringing the hole to its final depth of 2,699 ft. Drilling operations ended at about noon on May $26^{\text {th }}$. Drilling was followed immediately by the final stage of geophysical logging in the open-hole section, from the total depth of 2,699 ft to the bottom of casing at $394 \mathrm{ft}$. Caliper, multifunction, acoustic televiewer, sonic-velocity, neutron-porosity, and gamma-gamma density logs were acquired at that time.

\section{Drilling Rate}

The time needed to drill a given depth interval was recorded for most drilling runs in USGS-STP2. The recorded times are for 20-ft drilling runs above a depth of 2,440 ft and 10-ft coring runs below $2,440 \mathrm{ft}$. The 20 -ft intervals correspond to the collection intervals for cuttings samples. Drill penetration rates varied between 0.4 and $1.8 \mathrm{ft} / \mathrm{min}$ in the postimpact sediments above a depth of 1,163 ft (Fig. 4). Typically slower penetration rates occurred in the sediment-clast breccias of the impact structure between depths of $1,163 \mathrm{ft}$ and 2,150 ft, generally in the range of 0.2 to $1.0 \mathrm{ft} / \mathrm{min}$ with faster rates in the sandier sections. Penetration rates in the crystalline-clast breccias below 2,150-ft depth were similar to those in the sediment-clast breccias. Coring runs below a depth of 2,440 ft had the slowest penetration rates, typically less than $0.3 \mathrm{ft} / \mathrm{min}$. 


\section{Drill Penetration Rate}

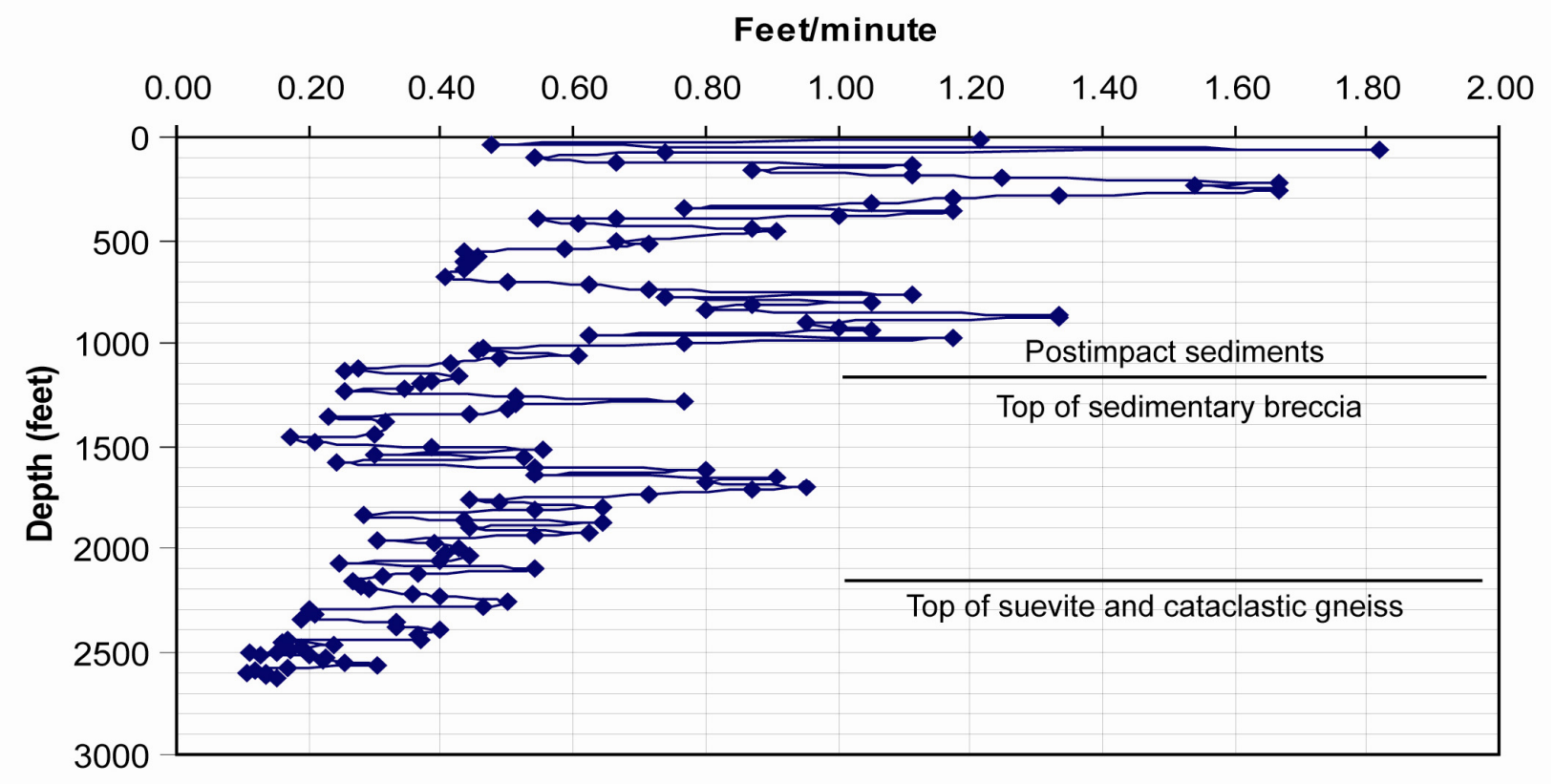

Figure 4. Drill penetration rate for the USGS-STP2 test hole.

\section{Coring Runs}

Twenty-nine coring runs were completed in the USGS-STP2 hole (Table 1). Two coring runs were conducted within sediment-clast breccias of the impact structure between depths of $1,401.7$ and $1,420.7 \mathrm{ft}$. Twenty-seven coring runs were conducted in a section of crystalline-clast breccia and cataclastic gneiss between depths of 2,440 and 2,699 ft. A total of $278 \mathrm{ft}$ of section was drilled with the core-sampling system.

Core recovery was moderately low (48.8 percent), owing in part to the alternation of hard and soft rocks within the breccia-gneiss section. Four coring runs recovered more than 70 percent of the drilled section, and five runs recovered less than 30 percent.

Cuttings samples were collected from the uncored intervals in USGS-STP2 below a depth of $280 \mathrm{ft}$. Individual cuttings samples generally represent $20 \mathrm{ft}$ of section, equivalent to the $20-\mathrm{ft}$ lengths of the drilling rods. The depth reference point for all core and cuttings samples was the land surface. 
Table 1. Data for coring runs in the USGS-STP2 test hole.

[The indicated depths are listed as reported by the lead driller.]

\begin{tabular}{|c|c|c|c|c|c|c|c|c|}
\hline Core & $\begin{array}{l}\text { Top } \\
\text { (ft) }\end{array}$ & $\begin{array}{c}\text { Bottom } \\
\text { (ft) }\end{array}$ & $\begin{array}{l}\text { Top } \\
\text { (m) }\end{array}$ & $\begin{array}{c}\text { Bottom } \\
\text { (m) }\end{array}$ & $\begin{array}{c}\text { Recovery } \\
\text { (ft) }\end{array}$ & $\begin{array}{c}\text { Recovery } \\
\text { (m) }\end{array}$ & $\begin{array}{c}\text { Recovery } \\
(\%)\end{array}$ & Comments \\
\hline 1 & 1401.7 & 1410.7 & 427.24 & 429.98 & 8.6 & 2.62 & $95.6 \%$ & Loss at bottom; short run \\
\hline 2 & 1410.7 & 1420.7 & 429.98 & 433.03 & 4.9 & 1.49 & $49.0 \%$ & Loss at bottom \\
\hline 3 & 2440.0 & 2450.0 & 743.71 & 746.76 & 4.6 & 1.40 & $46.0 \%$ & Loss at bottom \\
\hline 4 & 2450.0 & 2460.0 & 746.76 & 749.81 & 5.1 & 1.55 & $51.0 \%$ & Loss at bottom \\
\hline 5 & 2460.0 & 2470.0 & 749.81 & 752.86 & 6.3 & 1.92 & $63.0 \%$ & Loss at bottom \\
\hline 6 & 2470.0 & 2480.0 & 752.86 & 755.90 & 3.2 & 0.98 & $32.0 \%$ & Loss at bottom \\
\hline 7 & 2480.0 & 2490.0 & 755.90 & 758.95 & 5.2 & 1.58 & $52.0 \%$ & Loss at bottom \\
\hline 8 & 2490.0 & 2500.0 & 758.95 & 762.00 & 4.2 & 1.28 & $42.0 \%$ & Loss at bottom \\
\hline 9 & 2500.0 & 2510.0 & 762.00 & 765.05 & 3.5 & 1.07 & $35.0 \%$ & Loss at bottom \\
\hline 10 & 2510.0 & 2515.0 & 765.05 & 766.57 & 3.1 & 0.94 & $62.0 \%$ & Loss at bottom; short run \\
\hline 11 & 2515.0 & 2522.0 & 766.57 & 768.71 & 3.0 & 0.91 & $42.9 \%$ & Loss at bottom; short run \\
\hline 12 & 2522.0 & 2529.0 & 768.71 & 770.84 & 1.0 & 0.30 & $14.3 \%$ & Loss at bottom; short run \\
\hline 13 & 2529.0 & 2539.0 & 770.84 & 773.89 & 3.4 & 1.04 & $34.0 \%$ & Loss at bottom \\
\hline 14 & 2539.0 & 2549.0 & 773.89 & 776.94 & 3.5 & 1.07 & $35.0 \%$ & Loss at bottom \\
\hline 15 & 2549.0 & 2559.0 & 776.94 & 779.98 & 0.2 & 0.06 & $2.0 \%$ & Loss at bottom \\
\hline 16 & 2559.0 & 2569.0 & 779.98 & 783.03 & 9.0 & 2.74 & $90.0 \%$ & Loss at bottom \\
\hline 17 & 2569.0 & 2579.0 & 783.03 & 786.08 & 6.6 & 2.01 & $66.0 \%$ & Loss at bottom \\
\hline 18 & 2579.0 & 2589.0 & 786.08 & 789.13 & 5.1 & 1.55 & $51.0 \%$ & Loss at bottom \\
\hline 19 & 2589.0 & 2599.0 & 789.13 & 792.18 & 1.9 & 0.58 & $19.0 \%$ & Loss at bottom \\
\hline 20 & 2599.0 & 2609.0 & 792.18 & 795.22 & 6.3 & 1.92 & $63.0 \%$ & Loss at bottom \\
\hline 21 & 2609.0 & 2619.0 & 795.22 & 798.27 & 2.7 & 0.82 & $27.0 \%$ & Loss at bottom \\
\hline 22 & 2619.0 & 2629.0 & 798.27 & 801.32 & 4.3 & 1.31 & $43.0 \%$ & Loss at bottom \\
\hline 23 & 2629.0 & 2637.0 & 801.32 & 803.76 & 2.3 & 0.70 & $28.8 \%$ & Loss at bottom; short run \\
\hline 24 & 2637.0 & 2649.0 & 803.76 & 807.42 & 3.9 & 1.19 & $32.5 \%$ & Loss at bottom; long run \\
\hline 25 & 2649.0 & 2659.0 & 807.42 & 810.46 & 5.3 & 1.62 & $53.0 \%$ & Loss at bottom \\
\hline 26 & 2659.0 & 2669.0 & 810.46 & 813.51 & 6.7 & 2.04 & $67.0 \%$ & Loss at bottom \\
\hline 27 & 2669.0 & 2679.0 & 813.51 & 816.56 & 9.0 & 2.74 & $90.0 \%$ & Loss at bottom \\
\hline 28 & 2679.0 & 2689.0 & 816.56 & 819.61 & 9.0 & 2.74 & $90.0 \%$ & Loss at bottom \\
\hline \multirow[t]{2}{*}{29} & 2689.0 & 2699.0 & 819.61 & 822.66 & 3.8 & 1.16 & $38.0 \%$ & Loss at bottom \\
\hline & & & & Totals: & 135.7 & 41.36 & $48.8 \%$ & \\
\hline
\end{tabular}

\section{Geophysical Logging}

Geophysical logging of the USGS-STP2 test hole was conducted in four stages at depths of $394 \mathrm{ft}, 1,400 \mathrm{ft}$ and 2,699 ft (Table 2). Geophysical tools consisted of the caliper, multifunction, full-waveform sonic velocity, neutron porosity, and gamma-gamma density probes. More information regarding the principles of operation of these logging tools can be found in Hearst and others (2000). A composite of the geophysical logs collected and analyzed from test hole USGSSTP2 is shown in Figure 5. The individual logs obtained from the four separate logging runs have been spliced together and have undergone a simple smoothing process to reduce high-frequency variations and improve visual recognition of trends at the scale of the plots. All log depths are referenced to land surface. 
Table 2. Record of geophysical logging activities in the USGS-STP2 test hole.

Logging Runs

Date

Start Time

Nominal top

logged interval (ft)

Nominal base

logged interval (ft)

Base drilled interval (ft)

Probes

(depth interval, $\mathrm{ft}$ )
Run 1A

May 12, 2004

12:30 AM

0

$125 / 390$

394

Caliper

(to 390)

Multifunction

(to 125)

- - -

Sonic

(to 120)
Run 1B

May 12, 2004

9:55 AM

0

394

394

Caliper

(to 394)

Density

(26-377)

Multifunction

(to 394)

Porosity

(26-394)

Sonic

(180-390)
Run 2

May 17, 2004

10:30 AM

400

1,400

1,400

Caliper

(395-1,400)

Density

(140-1,400)

Multifunction

(397-1,400)

Sonic

(404-1,400)
Run 3

May 26-27, 2004

4:30 PM

1,400

2,699

2,699

Caliper

(400-2,699)

Density

(1,360-2,430)

Multifunction

(1,337-2,687)

Porosity

(80-2,655)

Sonic

$(1,390-2,440)$
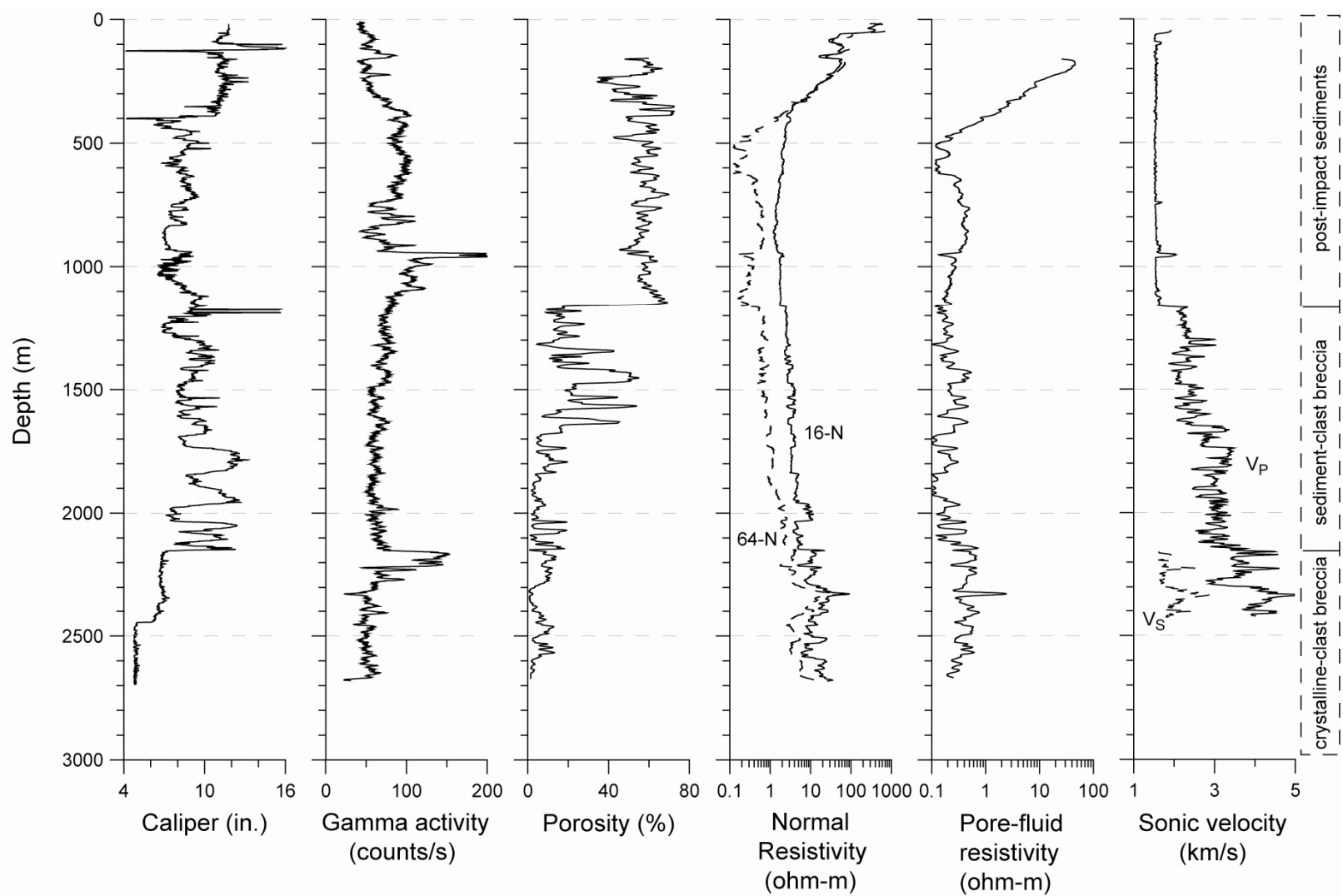

Figure 5. Composite of geophysical logs obtained in test hole USGS-STP2. See list of Conversion Factors (above) to convert SI units to Inch/Pound units. 
An attempt was made during the final logging stage to record an acoustic televiewer log across a depth interval where the hole was reasonably intact and its diameter fairly uniform $(2,380$ $\mathrm{ft}$ to 2,430 ft). This tool provides magnetically oriented images of the borehole wall from which fractures, bedding, and other features may be identified and oriented. Regrettably, this run was unsuccessful due to the presence of thick mud in the hole that inhibited the transmission of acoustic pulses to the wall and back again to the tool transmitter-receiver. In addition, data acquired from the gamma-gamma density tool generally were unreliable and of poor quality, primarily because of large variations in borehole diameter that could not be adequately compensated by the tool. Consequently, acoustic televiewer data and density values are not included in the plots of Figure 5.

The three-arm caliper tool provides an approximate measure of borehole diameter. The three arms do not operate independently, and the resulting response is considered to be an average estimate of hole diameter. The caliper log in Figure 5 displays substantial enlargements in borehole diameter within the postimpact sediments and the sediment-clast breccia that extend well beyond bit gauge. This is indicative of a very unstable borehole and mechanically weak geologic materials. Conditions improve markedly below $2,150 \mathrm{ft}$ in the more competent breccia-gneiss section, and the replacement of the drilling bit with the coring bit near 2,440 ft is recognized as a step reduction in diameter at $2,444 \mathrm{ft}$.

The multifunction tool is equipped to measure natural gamma activity, electrical resistivity, borehole fluid conductivity, and borehole fluid temperature. Borehole fluid conductivity and temperature data were not useful under these field conditions because of the significant disturbances to the fluid column imposed by numerous episodes of mud circulation required during drilling. Therefore, logs of borehole fluid properties are not included in this report. The gammaactivity $\log$ is a measure of natural gamma radiation being emitted by the surrounding rocks and sediments. Clays tend to accumulate radioisotopes through adsorption and ion-exchange processes, and zones of high gamma activity are typically interpreted as being clay rich. Feldspathic sandstones, phosphatic limestones, and glauconitic sands also are associated with high gamma responses. Two zones that display increased gamma counts in Figure 5 are present in the lower part of the postimpact sediments $(940 \mathrm{ft}$ to $1,150 \mathrm{ft})$ and the upper part of the breccia-gneiss section $(2,150 \mathrm{ft}$ to $2,220 \mathrm{ft})$.

Electrical resistivity measurements consisted of short-normal (16-inch) and long normal (64-inch) resistivities, also referred to as near and far resistivities, respectively. Saturated formation resistivity is primarily a function of porosity, pore-fluid resistivity, and mineralogy. It typically correlates positively with grain size and negatively with porosity. A lower resistivity corresponds to higher porosity or to smaller grain size because the surface area associated with fine particles promotes the transmission of electric current (Biella and others, 1983; Kwader, 1985). In addition, resistivity profiles are often effective in identifying freshwater-seawater interfaces.

Plots of the 16-inch (solid line) and the 64-inch (dashed line) resistivity logs are displayed in Figure 5 at a logarithmic scale. The separation between the two plots is attributed to the presence of a drilling mud that is more resistive than seawater but less resistive than fresh water. The far measurement (64-inch) has a greater volume of investigation beyond the borehole and is proportionally less influenced by drilling mud than is the near measurement (16-inch). The logs depict a gradual downward transition from freshwater to seawater in the upper $400 \mathrm{ft}$, with the far resistivity being slightly greater than the near one. Below this zone, the far measurement is consistently less than the near resistivity due to the salinity of the saturating pore fluid, although the difference is very small (logarithmic scale). Slight incremental increases in resistivity are seen at both major lithologic contacts $(1,163 \mathrm{ft}$ and $2,150 \mathrm{ft})$.

The neutron probe used in this study was a single-detector epithermal tool that yields an estimate of saturated formation porosity. This tool has been calibrated in specially designed test 
pits, and the response of the neutron detector, in counts per second, can be accurately converted to quantitative values of total porosity provided the formation is saturated. This estimate of total porosity includes both free water and bound water on clay surfaces. The porosity profile presented in Figure 5 shows a marked shift at the sediment-breccia contact $(1,163 \mathrm{ft})$ that clearly distinguishes between the high-porosity postimpact marine sediments (porosity $\sim 60$ percent) and the underlying sediment-clast breccia (porosity $~ 20$ percent). The porosity estimates for the postimpact sediments, in the range of roughly 50 to 65 percent, are in good agreement with laboratory measurements conducted on various core samples from other drillholes (W. E. Sanford, USGS); porosities of the sediment-clast breccia are also in general agreement with core-derived data from other drill holes (E.R. McFarland, USGS, written communication).

The porosity and the resistivity logs were combined to arrive at estimates of pore-fluid resistivity using Archie's law (Archie, 1942), after making some general assumptions about cementation and grain size and shape. The far resistivity was used in this calculation because it was considered to be less affected by drilling-mud invasion into the formation than was the near resistivity. The resulting plot of resistivity of the saturating pore fluid is shown in Figure 5 at a logarithmic scale, and it tends to mimic the 64-inch resistivity log. The pore fluid appears to be fresh water near the surface ( 40 ohm-meters $)$, but gradually changes to brackish water ( 4 ohmmeters) and finally to seawater ( 0.4 ohm-meter) below $500 \mathrm{ft}$.

The full-waveform sonic tool is equipped with a variable frequency transmitter and three receivers. Logs were obtained at a frequency of $10 \mathrm{kHz}$ and were later processed by means of a semblance technique (Paillet and Cheng, 1991) to arrive at estimates of sonic velocities. Plots of compressional-wave velocity $\mathrm{V}_{\mathrm{P}}$ (solid line) and shear-wave velocity $\mathrm{V}_{\mathrm{S}}$ (dashed line) are presented in Figure 5. A log of the compressional-wave velocity was constructed from the full waveforms down to 2,440 ft. This profile clearly delineates the contact between the postimpact sediments and the underlying sediment-clast breccia at $1,163 \mathrm{ft}$ and indicates that the value of $\mathrm{V}_{\mathrm{p}}$ in the sediments approaches that of water alone $(\sim 1.55 \mathrm{~km} / \mathrm{s})$. Below this contact, the compressional-wave velocities gradually increase downward in the sediment-clast breccia. Below 2,150 ft, $\mathrm{V}_{\mathrm{P}}$ increases to almost $5 \mathrm{~km} / \mathrm{s}$ as the rocks become more indurated and mechanically competent. Because of poor sampling conditions (borehole enlargements, mud invasion), it was difficult to transmit enough energy into the surrounding rocks to generate a detectable shear wave in all but the hardest rocks. Consequently, the plot of $\mathrm{V}_{\mathrm{s}}$ is limited to only the lowermost breccia-gneiss section, where $\mathrm{V}_{\mathrm{S}}$ is roughly half the velocity of $\mathrm{V}_{\mathrm{P}}$. These values fall within a well-constrained lithology band presented by Paillet and Cheng (1991).

\section{Well Installation}

Well installation in USGS-STP2 began on May $27^{\text {th }}$ following the geophysical logging and lasted about three days. Two wells were completed in this single borehole (Fig. 6). Both wells were constructed of 2.5-inch-diameter, schedule-80, flush-jointed PVC with 20-ft stainless-steel, wire-wrap screens and 5-ft stainless-steel sumps. The deep well and shallow well were assigned USGS unique numbers $62 \mathrm{G}-24$ and $62 \mathrm{G}-25$, respectively. The screen of the deep well was installed between 2,260 ft and 2,280 ft with the sump extending to 2,285 ft. The screen of the shallow well was installed between 1,360 ft and 1,380 ft with the sump extending to 1,385 ft. The screen locations were chosen based on the formation lithologies and geophysical logs. 
The annular spacing around the wells was filled with a combination of pea gravel, bentonite pellets, and bentonite grout. The section of the hole beneath the bottom screen, from 2,320 ft to $2,699 \mathrm{ft}$, was plugged with abandonment bentonite grout. The section around the deep screen, from $2,070 \mathrm{ft}$ to $2,320 \mathrm{ft}$, was filled with pea gravel. A section above the pea gravel from 2,010 ft to $2,070 \mathrm{ft}$ was then filled using bentonite pellets with minor amounts of pea gravel. The section from there up to the shallow screen, from $1,415 \mathrm{ft}$ to $2,010 \mathrm{ft}$, was filled with a high-solids abandonment bentonite grout. A short section below the shallow screen, from 1,400 ft to 1,415 ft, was filled using bentonite pellets with minor amounts of pea gravel. The area around the shallow screen, from $1,300 \mathrm{ft}$ to $1,400 \mathrm{ft}$, was filled with pea gravel. Another short section above the gravel, from $1,275 \mathrm{ft}$ to $1,300 \mathrm{ft}$, was filled using bentonite pellets with minor amounts of pea gravel. The remaining hole down to $1,275 \mathrm{ft}$ was filled with a high-solids abandonment bentonite grout, except for the top $10 \mathrm{ft}$, which was finished with cement.

The wells were developed using air immediately following their installation. Air was injected at high flow rates at about $500 \mathrm{ft}$ below land surface, which brought a combination of air, mud, and formation fluid to the land surface. The air development was continued for a time period of ten hours before the drilling crew returned to Denver for a break. The crew returned about a week later to pack their equipment and drive back to Denver. The drilling mud was made with fresh water, which was used as one indicator of the extent to which the wells were developing. The deep well produced water at a decent rate such that, after ten hours, salt water was the dominant fluid coming out of the hole. The shallow well, however, had a lower yield, such that after ten hours the fresh-water-based drilling fluid had not been completely purged from the well.

Slug tests were performed on the wells on October 29, 2004, before the purging continued. At this point in time, the water level in the deep well was $5.83 \mathrm{ft}$ bmp (below the measuring point, i.e., the top of the well casing), and the shallow well was shut in with a pressure of 5 psi. The artesian head on the shallow well was attributed to the fresh drilling fluid (less dense than the formation water) that remained in the well casing. The deep well was drawn down to $28 \mathrm{ft}$ bmp after pumping for 15 minutes at a rate of about $1 \mathrm{gpm}$. The pump was then turned off and the water level recovered to $7.8 \mathrm{ft}$ bmp after 45 minutes. The shallow well was drawn down to $31 \mathrm{ft}$ bmp after pumping for 15 minutes at a rate of about $1 \mathrm{gpm}$. The pump was then turned off and the water level recovered to $11.6 \mathrm{ft}$ bmp after 7 hours.

The purging process was continued beginning in May 2005 using a remote system consisting of pumps, data loggers, pressure transducers, conductivity meters, on/off switches for the pumps, and a solar panel. The wells were purged remotely for over a month until the conductance of the discharging fluids stabilized. The wells were then sampled on June 28, 2005. Final salinities of the waters stabilized at 40 parts per thousand for the deep well and 20 parts per thousand for the shallow well. The water level in the shallow well eventually stabilized below the top of the well casing at some time during the summer of 2005. 


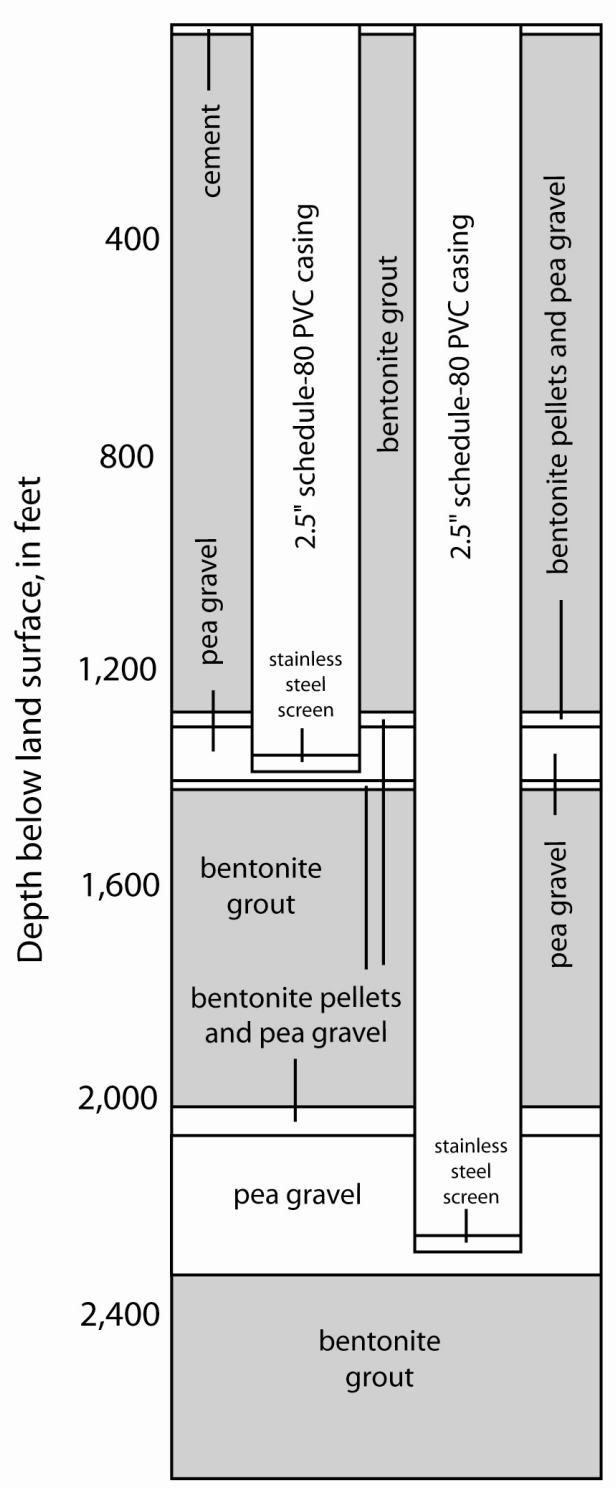

Figure 6. Diagram showing water wells 62G-24 (deep well) and 62G-25 (shallow well) in the USGSSTP2 test hole.

\section{Preliminary Site Geology}

The geologic section in the USGS-STP test holes consists of three major units (Sanford and others, 2004; Horton and others, 2004, 2005b): (1) a lower impact-structure section of crystallineclast breccia and cataclastic gneiss, (2) an upper impact-structure section of sediment-clast breccia, and (3) postimpact sediments (Figs. 5, 7).

The lower and upper impact-structure sections are present from the base of the test hole at 2,699- $\mathrm{ft}$ depth to $1,163-\mathrm{ft}$ depth, for a total penetrated thickness of $1,536 \mathrm{ft}$. These sections are separated by a contact at 2,150-ft depth. Thus, the section of crystalline-clast breccia and cataclastic gneiss is at least $549 \mathrm{ft}$ thick, and the section of sediment-clast breccia is $987 \mathrm{ft}$ thick. The postimpact section extends from 1,163 ft depth to the land surface. 


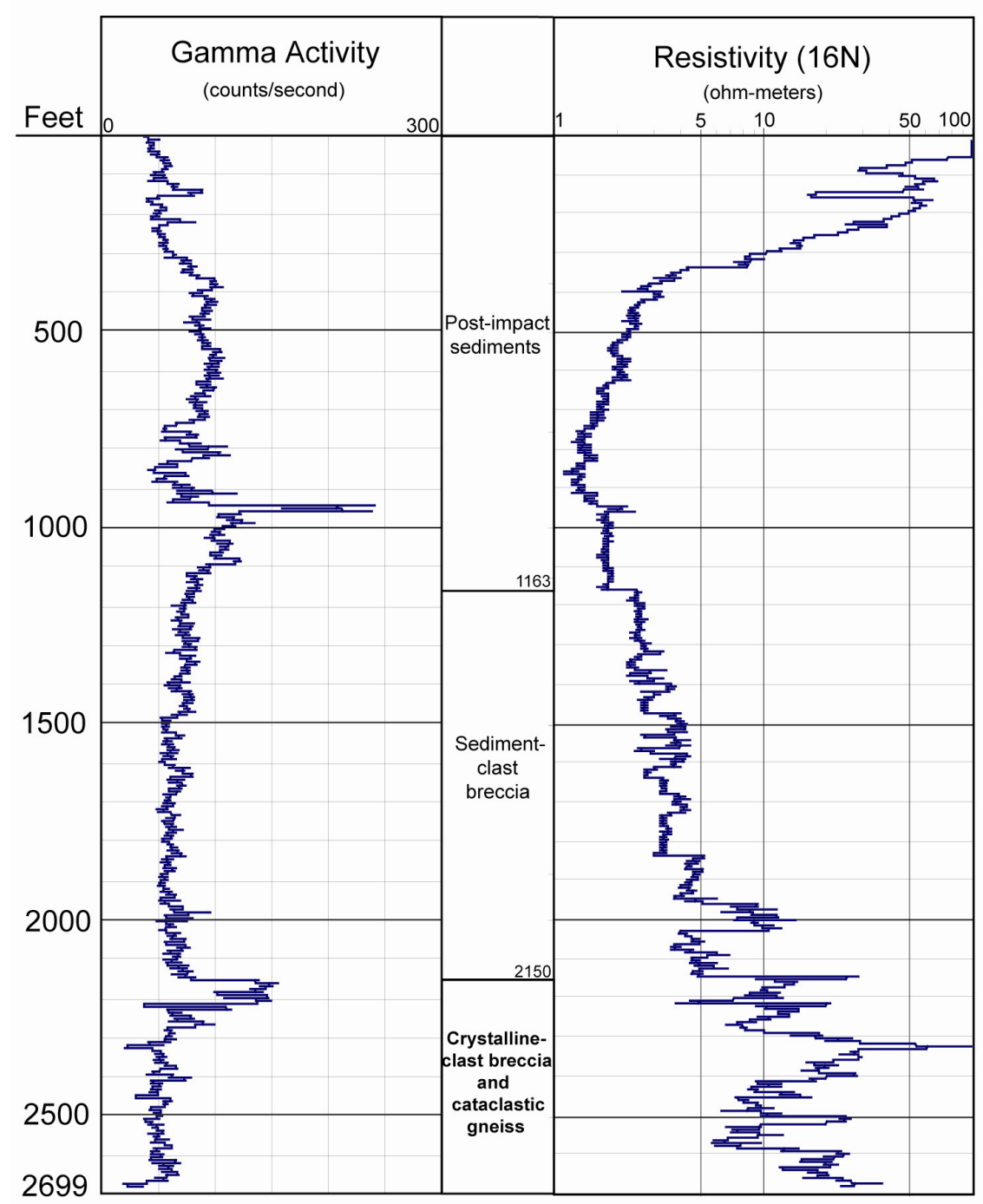

Figure 7. Generalized geologic column, and gamma-activity and short-normal-resistivity logs, from the USGS-STP2 test hole.

\section{Crystalline-clast Breccia and Cataclastic Gneiss}

The deepest part of the USGS-STP2 section consists primarily of crystalline-clast breccia and cataclastic gneiss. The upper contact of this rock unit is defined at 2,150 ft depth by the appearance of abundant crystalline-rock chips in the drill cuttings. This contact also is coincident with down-hole increases in resistivity, compressional velocity, and natural gamma activity on the borehole geophysical logs (Figs. 5, 7). Drill cuttings below 2,150 ft contain chips of granitic rock, gneiss, slaty rock, and minor fine-grained mica schist, in addition to clay and sand from higher levels in the test hole.

Drill cores were obtained from 2,440 ft to the base of the test hole at 2,699 ft depth. This cored section consists of polymict crystalline-clast breccia, cataclastic quartzofeldspathic gneiss, slate and slaty metasiltstone, and smaller amounts of cataclastic chlorite-rich mafic rock (Horton and others, 2005c). Some of the crystalline-clast breccia is suevite (Horton and others, 2004, 
2005c), meaning that it contains clasts of impact-melt rock (see Lee and others, 2006), although clasts of quartzofeldspathic gneiss and chloritic mafic rock are more abundant. The suevitic breccia is crumbly to moderately cohesive.

Minerals in the crystalline-clast breccia and cataclastic gneiss include plagioclase (mainly albite), quartz, chlorite, minor calcite, and traces of pyrite (Horton and others, 2005c). The rocks also contain shocked quartz and other shocked minerals (Horton and others, 2004, 2005c; Jackson and others, 2006). Secondary chlorite and albite are attributed to hydrothermal alteration (Horton and others, 2004, 2005b; Sanford, 2005).

\section{Sediment-Clast Breccia}

The central part of the test-hole section is interpreted to consist of sediment-clast breccias that are typical of the sediment-clast breccias found throughout the Chesapeake Bay impact structure (Powars and Bruce, 1999; Poag and others, 2004; Horton and others, 2005b). The top of this breccia in the USGS-STP2 test hole is marked by the first (highest) down-hole appearance of abundant loose granules and medium to very coarse sand that consist primarily of quartz, glauconite, and feldspar, along with drilling chips that consist of a wide variety of sediments and crystalline rocks. This first appearance is in the upper part of the cuttings sample from 1,160 to $1,170 \mathrm{ft}$. The naturally heterogeneous composition of the sediment-clast breccia, combined with the mixing and caving of cuttings produced by rotary drilling, prevents the identification of all but the broadest lithologic trends within this section in USGS-STP2.

Loose grains in the breccia cuttings consist of quartz, glauconite, and feldspar with minor amounts of shell fragments, white mica, and pyrite and trace amounts of microfossils, wood, phosphate, and fish teeth. Coherent chips of sediment in the cuttings primarily consist of silty clays and clayey silts in a wide variety of colors. Chips of oxidized clayey silts and sands from the Cretaceous Potomac Formation are particularly common, whereas soft chips of muddy glauconitic sand from the breccia matrix are rare. Caved chips from the postimpact sedimentary section encountered higher in the test hole also are common, including cemented quartz-glauconite sand, muddy quartz sand, and shelly limestone.

Chips of crystalline rocks in the breccia cuttings primarily consist of granitic rocks and chert. Less common rock types include light-red or light-gray felsite, chloritic gneiss, diabase, slate, and finely crystalline or aphanitic mafic rocks.

Two runs recovered $13.5 \mathrm{ft}$ of core from the interval between depths of 1,401.7 ft to 1,420.7 $\mathrm{ft}$. The cored material is heterogeneous and contains: (1) glauconite-bearing quartz sand that contains mixed-age and impact-damaged microfossils and darkened plant debris, (2) massive coarse to very coarse sand with granules and pebbles (possible fluidized Cretaceous sand), (3) medium to coarse sands that show high angle lamination (possible clasts of Cretaceous sediment), (4) sand with clay clasts up to 2 inches (possible fluidized Cretaceous sand or clast), (5) a one-footthick concentration of pebbles up to 1.2 inches, where the pebbles are rounded to angular and include quartz, rock fragments, and clasts of red silty clays. Contacts between these lithologies are sharp.

The geophysical logs show general increases in resistivity and compressional velocity, and a general decrease in porosity, with increasing depth within the sediment-breccia section (Fig. 5, 7). Lithification of the clay cuttings from the sediment-clast breccia also progressively increases with depth. These trends may indicate postimpact compaction, early postimpact hydrothermal alteration, or both. A more abrupt downward increase in compressional velocity and a more abrupt downward decrease in porosity near 1,650 ft depth may indicate increases in the number and size of sediment clasts that have retained their preimpact densities. Below about 1,650 ft, the log patterns 
suggest intervals of relatively uniform lithology that may represent sediments blocks that are tens of feet, to perhaps $100 \mathrm{ft}$, in thickness.

Regionally within the impact structure, the lower part of the sediment-clast breccia consists of blocks and megablocks (tens to hundreds of feet in diameter) of pre-impact sediments within a matrix of exotic and (or) locally derived sediments (Powars and Bruce, 1999; Poag and others, 2004; Gohn and others, 2005). In the outer part of the structure, the sediment blocks are primarily autochthonous to parautochthonous, having been disrupted in place by the impact. In the central part of the structure, the sediment blocks are allochthonous, having slumped into the central part of the impact structure during late-stage gravitational collapse.

The informally defined Exmore beds (Powars et al., 1992) constitute the upper part of the sediment-clast breccia throughout the structure. As seen in other cored test holes, the Exmore beds consist of abundant pebbles, cobbles, and small boulders of preimpact Cretaceous and lower Tertiary sediments and sparse pebbles and cobbles of preimpact crystalline rocks dispersed in an unstratified and unsorted matrix of calcareous, muddy, quartz-glauconite sand and granules (Powars and Bruce, 1999; Poag and others, 2004; Gohn and others, 2005). These materials are interpreted to represent ocean-resurge deposition within the impact structure.

The transition from synimpact to postimpact sedimentation is marked by a thin interval of laminated, clayey sands and silts in coreholes drilled within the impact structure (Poag and others, 2004; Powars and others, 2005). A few laminated silt and clay chips found in the cuttings may indicate the presence of a similar transition zone in the USGS-STP2.

\section{Postimpact Sediments}

\section{Upper Eocene Section - Chickahominy Formation (1,163ft to $993 \mathrm{ft})$}

Upper Eocene sediments in the USGS-STP2 test hole were sampled only as cuttings from depths of about 1,163 ft to $993 \mathrm{ft}$. The lower contact with the sediment-clast breccia was picked on the basis of the first (highest) down-hole appearance of abundant glauconite and lithic fragments in the run from 1,180-ft to 1,160-ft depth. There also are sharp down-hole increases in resistivity and compressional velocity, and a sharp down-hole decrease in porosity, between depths of $1,165 \mathrm{ft}$ and 1,162 ft (Figs. 5, 7).

The upper contact of the upper Eocene sediments with the overlying Oligocene sediments was difficult to pick during drilling because the Eocene lithology returned few cuttings and tended to form "clay boots" (clay adhering to the drill bit and rods), particularly when a roller bit were used instead of a wing bit. The upper contact was placed at $993-\mathrm{ft}$ depth by comparison of the USGS-STP2 gamma-activity log with the equivalent log from the USGS-Watkins School corehole, located in Newport News, Va. (Edwards and others 2004b), and the onsite observation of a sandier interval in the middle of the 1,000-ft to 980 -ft interval.

The upper Eocene sediments in the USGS-STP2 hole are approximately $179 \mathrm{ft}$ thick and are assigned to the Chickahominy Formation. This unit is known only in the subsurface and only in the vicinity of the Chesapeake Bay impact structure (Powars and Bruce, 1999; Poag and others, 2004). Chickahominy cuttings from the USGS-STP2 test hole consist of very stiff, very clayey silt that contains sparse to abundant foraminifera, local shell fragments, and a trace to 2 percent of glauconite in the silt to very fine sand fraction. The sediment color is olive gray (5Y3/2) to grayish olive (10Y4/2). Minor variations in the drilling speed likely reflect minor variations in grain size (Fig. 4). 


\section{Oligocene Section - Delmarva Beds, Drummonds Corner Beds, Old Church Formation (993 to $955 \mathrm{ft}$ )}

Three Oligocene units are recognized in the subsurface of the Virginia Coastal Plain (Edwards and others, 2005; Powars and others, 2005). These are, in ascending order, the informal Delmarva beds, the informal Drummonds Corner beds, and the Old Church Formation. The lower two units are known only from the subsurface; the Old Church crops out in a thin band in the eastern Virginia mainland and also is present in the subsurface. These Oligocene units are recognized from 993-ft to 955-ft depth in the USGS-STP2 test hole on the basis of cuttings lithologies and comparison of the gamma-activity log with the equivalent log from the Watkins School corehole (Edwards and others, 2004b). The contact between the base of the Oligocene section (base of Delmarva beds) and the underlying Chickahominy Formation is placed at the base of a small gamma spike at 993-ft depth. (Fig. 7) The upper contact of the Oligocene section at 955 $\mathrm{ft}$ is placed at the base of the higher of two closely spaced, prominent gamma spikes (Fig. 7). Where dated by microfossils from corehole sections, sediments of the higher prominent gamma spike are early Miocene in age. Patterns of gamma spikes similar to the one seen in the USGSSTP2 log are typical of Oligocene sections in other drill holes in southeastern Virginia (Powars and Bruce, 1999). In the USGS-STP2 cuttings, a 0.24-inch phosphate pebble was recovered near the end of the run from $960 \mathrm{ft}$ to $940 \mathrm{ft}$.

Approximate depths for the Oligocene units in the USGS-STP2 hole are: Delmarva beds, $993 \mathrm{ft}$ to $980 \mathrm{ft}$; Drummonds Corner beds, $980 \mathrm{ft}$ to $962 \mathrm{ft}$; and Old Church Formation, $962 \mathrm{ft}$ to $955 \mathrm{ft}$. Cuttings from the Delmarva beds and Drummonds Corner beds consist of clayey silt that contains less conspicuous foraminifera and more prominent glauconite and (or) phosphate than the silts from the underlying Chickahominy. Cuttings from the Old Church Formation consist of brownish-black to olive-black glauconite-phosphate sand in a clayey silt matrix. Some of the recovered cuttings show burrows of sand into lighter colored clayey silt.

\section{Lower and Middle Miocene Section - Calvert and Choptank Formations (955 ft to $606 \mathrm{ft}$ )}

Lower and middle Miocene sediments are present at depths of about $955 \mathrm{ft}$ to about $606 \mathrm{ft}$ in the USGS-STP2 test hole. This 349-ft-thick interval consists primarily of clayey silt. The lower contact at $955 \mathrm{ft}$ is placed at the base of a characteristically large gamma-activity spike (Fig. 7) that is produced by phosphatic sediments and correlates well with the gamma-activity log from the nearby Kiptopeke corehole in Northampton County, Va. (Powars and Bruce, 1999). At Kiptopeke, this gamma spike represents the basal beds of the lower Miocene deposits that Powars and Bruce (1999) named the Newport News beds of the Calvert Formation. In the USGS-STP2 test hole, cuttings from the run at depths of $960 \mathrm{ft}$ to $940 \mathrm{ft}$ show the first down-hole appearance of shelly very fine to fine quartz sand with scattered fine to granular phosphate grains (fine pebbles). The upper contact is placed at 606-ft depth where an abrupt change in the drilling rate was recorded (Fig. 4).

These shallow-marine deposits are distinctly olive gray $(5 \mathrm{Y} 3 / 2)$ to olive gray $(5 \mathrm{Y} 4 / 1)$ to grayish olive (10Y4/2). The clayey silt has abundant microfossils (mostly foraminifera and diatoms) and sparse, scattered shell fragments. Glauconite $(<1 \%$ to $5 \%)$ is present locally, mica ( $1 \%$ to $3 \%$ ) is present, and very fine to fine quartz sand and very thin slightly sandier intervals are observable in cuttings.

Most of the lower and middle Miocene section in the USGS-STP2 test hole is considered to be the lower and middle Miocene Calvert Formation (Newport News beds and Fairhaven, Plum Point, and Calvert Beach Members); however, approximately the upper $20 \mathrm{ft}$ may represent the 
middle Miocene Choptank Formation. A thin Choptank Formation was identified in the updip Watkins School core (Edwards and others, 2004b) and correlation of the Watkins School gammaactivity log to the equivalent USGS-STP2 log suggests that the presence of the Choptank in the USGS-STP2 hole should be considered. Although Powars and Bruce (1999) did not identify a Choptank section in the Kiptopeke corehole, the dinocyst data of de Verteuil and Norris (1996; their highest sample assigned to the Calvert Formation) support the presence of the Choptank at Kiptopeke.

\section{Upper Miocene Section - St. Marys and Eastover Formations (606 ft to $168 \mathrm{ft}$ )}

Upper Miocene sediments in the USGS-STP2 test hole were sampled only as cuttings between depths of about $606 \mathrm{ft}$ and $168 \mathrm{ft}$. The lower contact is marked by a dramatic down-hole color change from dark greenish gray $(5 \mathrm{GY} 5 / 1$ to $5 \mathrm{GY} 4 / 1)$ to olive gray $(5 \mathrm{Y} 3 / 2)$ and an abrupt down-hole change to much denser, more brittle clayey silt that drilled significantly more slowly than the upper Miocene sediments (Fig. 4). There may be a thin cemented bed at the top of the underlying middle Miocene sediments. The lower contact also is marked by the down-hole appearance of fine sand with phosphate chips in the lower few feet of the upper Miocene section. The upper contact was picked on the basis of similarities between the USGS-STP2 gamma-activity $\log$ and the gamma-activity log for the Langley corehole (Powars and others, 2005). This contact is placed at the base of a high-gamma spike in the lower part of the overlying Pliocene section in the USGS-STP2 test hole (Fig. 7).

The lower $266 \mathrm{ft}$ of the upper Miocene section is assigned to the St. Marys Formation (606 $\mathrm{ft}$ to $340 \mathrm{ft}$ depth). This formation consists, in part, of a basal fine sand that is only a few feet thick. The basal sand is overlain by $50 \mathrm{ft}$ of very clayey silt, that is overlain, in turn, by silty clay that grades upward at about 440-ft depth into a clayey silt. The upper $172 \mathrm{ft}$ of the upper Miocene section is assigned to the Eastover Formation (340 ft to $168 \mathrm{ft}$ depth). The Eastover sediments are well sorted, variably shelly, silty, very fine to fine sand.

\section{Pliocene Section - Yorktown and Chowan River Formations (168 ft to $32 \mathrm{ft}$ )}

Sediments from depths of about $168 \mathrm{ft}$ to $32 \mathrm{ft}$ in the USGS-STP2 test hole are assigned to the Pliocene on the basis of cuttings descriptions and correlation of the geophysical logs with the nearby Kiptopeke corehole (Powars and Bruce, 1999). The lower contact with the underlying upper Miocene sediments was placed at 168-ft depth on the basis of comparisons with the Kiptopeke gamma-activity and resistivity logs. Cuttings logged at $180 \mathrm{ft}$ to $160 \mathrm{ft}$ included shelly (turritellids and Chesapecten), fine to medium quartz sand with bone fragments and phosphate and glauconite (up to 15\%), as well as silty fine sand with phosphate and glauconite (up to 10\%). The upper contact with the overlying Pleistocene Nassawadox Formation at a depth of $32 \mathrm{ft}$ is obvious, with yellow pebbly sand of the Nassawadox overlying dark-greenish-gray (5GY4/1), finer grained, shelly sands of the Pliocene section.

The Pliocene section is $136 \mathrm{ft}$ thick. The lower $22 \mathrm{ft}$ consists of grayish-green (10G4/2), variably shelly, fine to medium sand. The sediments above this basal sand are dark-greenish-gray (5GY4/1), clayey, silty, very fine to medium quartz sand with variable amounts of glauconite and phosphate (1\% to $50 \%$ ). Fragmental and perhaps whole mollusks shells appear to be concentrated locally into thin beds (about 1-ft-thick), which also contain glauconite and phosphate as coarse sand, granules, and pebbles up to 0.6 inches, and which may contain bone chips and sharks teeth. Clay and silt cuttings from the Pliocene interval are typically medium dark gray (N4) and have less shell material, but more common foraminifera and sponge spicules, than the sands. 
Following Mixon (1985) and Powars and Bruce (1999), most of the Pliocene section in the USGS-STP2 test hole is assigned to the Yorktown Formation. However, correlation with the Kiptopeke corehole (Powars and Bruce, 1999) suggests that the upper $28 \mathrm{ft}$ of the USGS-STP2 Pliocene section may represent the Chowan River Formation, which typically fills paleovalleys or overlies ravinements cut into the top of the Yorktown.

\section{Pleistocene Section - Nassawadox Formation (32 ft to $5 \mathrm{ft}$ )}

Cuttings recovered from the interval between depths of $32 \mathrm{ft}$ and $5 \mathrm{ft}$ in the USGS-STP test holes consist of poorly sorted, yellow to tan, fine to coarse sand with organic fragments (up to 5\%) and scattered shell fragments, which grades downward to a very coarse pebbly sand at the unit's base. The sand and pebbles are subrounded to rounded. These lithologies are consistent with Mixon's (1985) description of the marginal-marine, late Pleistocene Butlers Bluff Member of the Nassawadox Formation. The Butlers Bluff Member is mapped across the Franktown Plain (flat upland surface and adjacent bay-side terrace), which includes the Cape Charles area. The Butlers Bluff Member is interpreted as a southward-building complex of spit-platform sands and very shallow shoals.

\section{Modern Artificial Fill (5 ft to $0 \mathrm{ft}$ )}

Poorly sorted, pebbly, fine to coarse sand is present from a depth of about $5 \mathrm{ft}$ to the land surface. This material is interpreted as artificial fill that was emplaced during construction of the parking lot located adjacent to the drill site.

\section{Acknowledgments}

Wilma Aleman Gonzalez, James B. Murray, Joseph H. Murray, and Ellen L. Seefelt (USGS), and Daniel Larsen (Univ. of Memphis), worked as site geologists (Appendix A). Barbara Corland (USGS) assisted with the geophysical logging of the test hole. Mary Voytek and Julie Kirshtein (USGS) sampled the core for microbiological studies. Arthur C. Clark supervised the USGS drilling crew (Appendix A). We thank the Sustainable Technology Park, and especially Ray Otten, for access to their property and for their support during the drilling operations. We also thank T. Scott Bruce (Virginia Dept. of Environmental Quality) for sharing his expertise in the collection and description of drill cuttings and for acquiring the GPS location data. We thank Emily Phillips (USGS) for creating Figure 2. 


\section{References Cited}

Archie, G.E., 1942, The electrical resistivity log as an aid in determining some reservoir characteristics: Transactions, American Institute of Mining, Metallurgical and Petroleum Engineers, v. 146, p. 54-62.

Biella, G., Lozej, A., and Tabacco, I., 1983, Experimental study of some hydrogeophysical properties of unconsolidated porous media: Ground Water, v. 21, no. 6, p. 741-751.

de Verteuil, Laurent, and Norris, Geoffrey, 1996, Miocene dinoflagellate stratigraphy and systematics of Maryland and Virginia: Micropaleontology, v. 42, supplement, 172 p., 18 pls.

Edwards, L.E., Horton, J.W., Jr., and Gohn, G.S., 2004a, ICDP-USGS Workshop on deep drilling in the central crater of the Chesapeake Bay impact structure, Virginia, USA, September 22-24, 2003, Proceedings volume: U.S. Geological Survey Open-File Report 2004-1016, CD-ROM.

Edwards, L.E., Powars, D.S., Gohn, G.S., Horton, J.W., Jr., Litwin, R.J., and Self-Trail, J.M., 2004b, Inside the crater, outside the crater: Comparison of two cores in the Chesapeake Bay impact structure (abstract): Geological Society of America Annual Meeting and Exposition, Denver, CO, November 7-10, 2004, Abstracts with Programs, p. 266.

Edwards, L.E., Barron, J.A., Bukry, David, Bybell, L.M., Cronin, T.M., Poag, C.W., Weems, R.E., and Wingard, G.L., 2005, Paleontology of the upper Eocene to Quaternary postimpact section in the USGS-NASA Langley core, Hampton, Virginia, chap. H of Horton, J.W., Jr., Powars, D.S., and Gohn, G.S., eds., Studies of the Chesapeake Bay impact structure-The USGS-NASA Langley corehole, Hampton, Virginia, and related coreholes and geophysical surveys: U.S. Geological Survey Professional Paper 1688, p. H1-H47, plates H1-H9.

Emry, S.R., and Miller, Brian, 2004, Chesapeake Bay impact structure - 35 million years after and still making an impact, in Edwards, L.E., Horton, J.W., Jr., and Gohn, G.S., 2004, ICDPUSGS Workshop on deep drilling in the central crater of the Chesapeake Bay impact structure, Virginia, USA, September 22-24, 2003: U.S. Geological Survey Open-File Report 2004-1016, CD-ROM.

Gohn, G.S., Powars, D.S., Bruce, T.S., and Self-Trail, J.M., 2005, Physical geology of the impactmodified and impact-generated sediments in the USGS-NASA Langley core, Hampton, Virginia, chap. C of Horton, J.W., Jr., Powars, D.S., and Gohn, G.S., eds., Studies of the Chesapeake Bay impact structure-The USGS-NASA Langley corehole, Hampton, Virginia, and related coreholes and geophysical surveys: U.S. Geological Survey Professional Paper 1688, p. C1-C38.

Hearst, J.R., Nelson, P.H., and Paillet, F.L., 2000, Well Logging for Physical Properties, $2^{\text {nd }}$ ed., John Wiley \& Sons, New York, 483 p.

Horton, J.W., Jr., Gohn, G.S., Powars, D.S., Jackson, J.C., Self-Trail, J.M., Edwards, L.E., and Sanford, W.E., 2004, Impact breccias of the central uplift, Chesapeake Bay impact structure: Initial results of a test hole at Cape Charles, Virginia [abstract]: Geological Society of America Abstracts with Programs, v. 36, no. 5, p. 266, abstract 110-9.

Horton, J.W., Jr., Aleinikoff, J.N., Kunk, M.J., Gohn, G.S., Edwards, L.E., Self-Trail, J.M., Powars, D.S., and Izett, G.S., 2005a, Recent research on the Chesapeake Bay impact structure, USA Impact debris and reworked ejecta, in Kenkmann, T., Hörz, F., and Deutsch, A. eds., Large meteorite impacts III: Geological Society of America Special Paper 384, p. 147-170.

Horton, J.W., Jr., Powars, D.S., and Gohn, G.S., eds., 2005b, Studies of the Chesapeake Bay impact structure - The USGS-NASA Langley corehole, Hampton, Virginia, and related coreholes and geophysical surveys: U.S. Geological Survey Professional Paper 1688-A-K, separately paginated [453 p., 2 oversize figures]. 
Horton, J.W., Jr., Gohn, G.S., Jackson, J.C., Aleinikoff, J.N., Sanford, W.E., Edwards, L.E., and Powars, D.S., 2005c, Results from a scientific test hole in the central uplift, Chesapeake Bay impact structure, Virginia, USA [abstract]: Lunar and Planetary Science Conference XXXVI, Abstract 2003, 2 p.

Jackson, J.C., Horton, J.W., Jr., Chou, I., and Belkin, H.E., 2006, A shock-induced polymorph of anatase and rutile from the Chesapeake Bay impact structure, Virginia, USA: American Mineralogist, v. 91, p. 604-608.

Koeberl, Christian, Poag, C.W., Reimold, W.U., and Brandt, Dion, 1996, Impact origin of the Chesapeake Bay structure and the source of the North American tektites: Science, v. 271, no. 5253, p. 1263-1266.

Kwader, T., 1985, Estimating aquifer permeability from formation resistivity factors: Ground Water, v. 23, no. 6, p. 762-766.

Lee, S.R., Horton, J.W., Jr., and Walker, R.W., 2006, Confirmation of a meteoritic component in impact-melt rocks of the Chesapeake Bay impact structure, Virginia, USA-Evidence from osmium isotopic and PGE systematics: Meteoritics and Planetary Science, v. 41, no. 3, p. 819833.

McFarland, E. R., and Bruce, T.S., 2005, Distribution, origin, and resource-management implications of ground-water salinity along the western margin of the Chesapeake Bay impact structure in eastern Virginia, in Horton, J.W., Jr., Powars, D.S., and Gohn, G.S., eds., Studies of the Chesapeake Bay impact structure - The USGS-NASA Langley corehole, Hampton, Virginia, and related coreholes and geophysical surveys: U.S. Geological Survey Professional Paper 1688, p. K1-K32.

Mixon, R.B., 1985, Stratigraphic and geomorphic framework of uppermost Cenozoic deposits in the southern Delmarva Peninsula, Virginia and Maryland: U.S. Geological Survey Professional Paper 1067-G, 53 p.

Paillet, F.L., and Cheng, C.H., 1991, Acoustic Waves in Boreholes, CRC Press, Boca Raton, Florida, $264 \mathrm{p}$.

Poag, C.W., 1997, The Chesapeake Bay bolide impact -- A convulsive event in Atlantic Coastal Plain evolution, in Seagall, M.P., Colquhoun, D.J., and Siron, D., eds., Evolution of the Atlantic Coastal Plain -- sedimentology, stratigraphy, and hydrogeology: Sedimentary Geology, v. 108, no. $1-4$, p. $45-90$.

Poag, C.W., Koeberl, Christian, Reimold, W.U., 2004, The Chesapeake Bay Crater, Springer, New York, $522 \mathrm{p}$.

Powars, D.S., 2000, The effects of the Chesapeake Bay impact crater on the geologic framework and the correlation of hydrogeologic units of southeastern Virginia, south of the James River: U.S. Geological Survey Professional Paper 1622, 53 p.

Powars, D.S., and Bruce, T.S., 1999, The effects of the Chesapeake Bay impact crater on the geological framework and correlation of hydrogeologic units of the Lower York-James Peninsula, Virginia: U.S. Geological Survey Professional Paper 1612, 82 p.

Powars, D.S., Bruce, T.S., Edwards, L.E., Gohn, G.S., Self-Trail, J.M., Weems, R.E., Johnson, G.H., Smith, M.J., and McCartan, C.T., 2005, Physical stratigraphy of the upper Eocene to Quaternary postimpact section in the USGS-NASA Langley core, Hampton, Virginia, chap. G of Horton, J.W., Jr., Powars, D.S., and Gohn, G.S., eds., Studies of the Chesapeake Bay impact structure-The USGS-NASA Langley corehole, Hampton, Virginia, and related coreholes and geophysical surveys: U.S. Geological Survey Professional Paper 1688, p. G1-G44. 
Powars, D.S., Mixon, R.B., and Bruce, Scott, 1992, Uppermost Mesozoic and Cenozoic geologic cross section, outer coastal plain of Virginia, in Gohn, G.S., ed., Proceedings of the 1988 U.S.

Geological Survey Workshop on the Geology and Geohydrology of the Atlantic Coastal Plain: U.S. Geological Survey Circular 1059, p. 85-101.

Sanford, W.E., Gohn, G.S., Powars, D.S., Horton, J.W., Jr., Edwards, L.E., Self-Trail, J.M., and Morin, R.H., 2004, Drilling the central crater of the Chesapeake Bay impact structure: A first look: EOS, v. 85, no. 39, p. 369, 377.

Sanford W.E., 2005, A simulation of the hydrothermal response to the Chesapeake Bay bolide impact: Geofluids, v. 5, p. 185-201.

U.S. Geological Survey, 1968, Cape Charles, Va., 7.5-minute series topographic-bathymetric map, 1:24,000 scale, photo-revised 1986.

\section{Appendix A: Drill-Site Staff}

\section{Drillers}

USGS, Denver, Colo. Arthur C. Clark (Supervisor), Jeffery D. Eman (Field Foreman), Stephen J. Grant (Lead Driller), Robert R. Hunley (Lead Driller), Ronald A. Funkhouser, Michael J. Schulz, James O. Stull, and Michael E. Williams.

\section{Site Geologists and Biologists}

USGS, Reston, Va. Wilma B. Aleman Gonzalez, Lucy E. Edwards, Gregory S. Gohn, J. Wright Horton, Jr., Julie Kirshtein, James B. Murray, Joseph H. Murray, David S. Powars, Ward E. Sanford, Ellen L. Seefelt, Jean M. Self-Trail, and Mary A. Voytek.

University of Memphis, Memphis, Tenn. Daniel Larsen

\section{Geophysical Loggers}

USGS, Denver, Colo. Roger H. Morin and Barbara S. Corland 